\title{
Theorising Material Ecocriticism: From Abstract to Concrete
}

\author{
Suhasini B. Srihari
}

PhD Scholar, English

Jain deemed-to-be University

Bangalore, Karnataka, India

bssuhasini18@gmail.com

Dr. D. Yogananda Rao

Asst. Prof., English

Jain deemed-to-be University

Bangalore, Karnataka, India

\section{Abstract}

The material-turn in the millennial period brought in newer insights in the understanding of the relationship between the material and its users. It would be interesting to explore the trajectory from this point, for the New Materialism that came about was founded on drawing from multifarious disciplines - natural sciences, anthropology, psychology, philosophy, history, geology and cultural studies. Today, the theoretical framework of Ecocriticism has adopted several tenets of New Materialism and has evolved into 'Material Ecocriticism'. The present paper aims to study the latest development of ecocriticism in association with materialism, while paying particular heed to how 'matter' plays a pivotal role in constructing and communicating narratives. The study also looks at reading matter as an active agent in propelling any alterations in our relationship with nature. Along with a quick rereading of William Blake's selected poems, the study proceeds to highlight the importance of accurate 
interpretations that could bring about considerable changes in our attitudes toward the environment.

Keywords: Matter, Narrative, Communication, Material and Representation

The theoretical framework of ecocriticism has spread into various fields of inquiry and collaboration, with its recent being the Material Ecocriticism. This approach could be considered as an offshoot of the new materialist paradigm that came about in the millennium. Briefly, 'new materialism' could be described as a theoretical turn away from the persistent dualisms in modern and humanist traditions that influenced a large part of reading and are still present in much of cultural theory. New materialism implored us to look at our own existence as depended on material factors. In the history of philosophy, materialism has often remained a marginal approach, for there has been a host of immaterial facets that appeared to have taken the centre stage: language, consciousness, mind, soul, imagination, emotions, meanings, and so on. These have typically been presented as something far more important and above the rest of the material world, in a way, vaporising the significance of biological material or the physical matter. New materialism aimed to foreground material factors and claimed to reconfigure our relationship with 'matter', affirming that our existence is steered differently every time we strike a connection with these material factors (Coole and Frost 2).

Similar to the approaches of new materialists, material ecocriticism attempts to view 'material' or 'matter' in terms of agencies and the capabilities of causal links that these agencies have in altering the course of nature. In theory, material ecocriticism is an interdisciplinary field of inquiry which aids in rethinking the questions of agency, creativity, imagination, and narratives. This division of ecocriticism focuses on questioning the ontological primacy of the world. It calls forth a radical revision of the existing ideas about the physical reality enmeshed in the chemical and biological processes, which also carry ethical, political and cultural implications. In her essay, "Theorizing Ecocriticism: Toward a 
Postmodern Ecocritical Practice”, Serpil Oppermann (professor of Environmental Humanities) attempts to conflate ecocriticism with an ecocentric postmodern theory with the aim of developing a postmodern ecocritical approach. Ecocriticism as a theoretical field emerged (in 1990s) with the wide-spread ecological crisis, and it initiated an understanding of the natural world and literature. However, on theoretical grounds, ecocriticism is still confined to the parameters of literary realism, and is 'struggling with hermeneutical closure' while 'facing an ambivalent openness in its interpretative approach' (103). Many ecocritics drew their ecocritical applications from the perspectives of realist epistemology, and attempted to make ecocriticism as an open field of inquiry. But, in this process, they ignored the conceptual problems that the realist perspectives raised. They promoted a particular variant of ecocriticism - realist approach -in order to legitimise their study of literature through the lens of environmental values, thus creating a nexus between literature and the natural world. In doing so, they failed to recognise that every interpretive theory is conceived with 'language' at its centre. It is perhaps because of this sort of an ecocritical underestimation that much of the promising work in the field of eco-literary studies have not gone beyond just analyses of literary and environmental texts.

The journey from postmodern ecocriticism to material ecocriticism is best to be seen as a transitory movement rather than two distinct features. The realm of material ecocriticism in a way engulfs many aspects that sharply defined postmodern ecocriticism. Postmodern ecocriticism investigated the debate of 'representations', and has also shown the notion of representation as a problematic issue. Representations are a way of imitations, where the subject/object is depicted as close to being real as possible. However, representation of a/an subject/object also evokes meaning. Normally, the meanings that come into association, with the subject/object, are based on an interpretation which are present prior. Postmodernism tried to show how representations are constructed, that are subjected to change and are 
always ideologically produced thus contesting the mimetic postulate of representation and meaning making. It is here that we must recognise the complicated relationship between words, meanings and representations.

Michael Riffaterre, the French literary critic, argues that, 'the representation of reality is a verbal construct in which meaning is achieved by reference from words to words, not to things' (230). This debunks the fact that referentiality of literary meaning is simply assumed to be based on the sole interpretation of the narrative, meaning, there is a fallacy when the significance is singularly attributed to the description in the narrative. The representation of reality acts through verbal construct, and it attains more significance when the narrative is put to action, that is, reading a story, reciting a poem, or painting a picture. The form a text assumes and renders a meaning is also a key aspect in deciphering of the meaning in totality. Riffaterre claims that in deciphering a given text, the resultant would be the text's intrinsic dichotomy of mimetic and symbolic discourse. Now, the problem that is often overlooked is how the presence of any allegorical personifications usually modifies the nature of representation itself.

This is what Riffaterre refers to as the 'referential fallacy' (231), where the genesis of the text plays a lesser role while the reader's reaction is accounted as the value judgement. While the interpretation of a given text relies largely on the text-reader's relationship, a fundamental question is whether the resultant meaning is a presupposed act between the words in the text and the description of the actual subject/object or it is just an appearance and a rationalisation which synchronises representation and reality. For instance, William Blake's 'The Tyger', a poem from his collection, Songs of Experience (1794), glorifies the much-celebrated animal, tiger:

Tiger, tiger, burning bright

In the forest of the night, 
What immortal hand or eye,

Could Frame thy fearful symmetry? (34)

Blake draws out images in this poem that are so compelling, and the readers have an immediate and overwhelming impression of a powerful creature wandering in the darkness. If Blake's earlier poem, 'The Lamb', from the collection, Songs of Innocence (1789), were to be set parallel in reading, then the intrinsic mimetic and symbolic meanings come to the forefront.

The lamb and the tiger become symbols of different phases in the human soul. As Maurice Bowra explains, '[w]hen the lamb is destroyed by experience, the tiger is needed to restore the world' (49). The two animals in the poems stand to represent two realms of reality which are partial and by being incomplete compels the reader to read the two realms as complementary to each other. The verbal construct suffices to lend meaning to the mimetic and any metaphorical connotations; however, the reality is not fully represented nor is the interpretation complete. If the poem on tiger could be understood in terms of the various 'matter' present rather than merely tending to its suggestive metaphorical meaning, then we would perhaps arrive at 'narrative agencies of storied matter' (Oppermann 2013: 57). It is imperative to notice that matter, that is, the physical reality is enmeshed in narrative agencies:

What the hammer? what the chain?

In what furnace was thy brain?

What the anvil? what dread grasp

Dare its deadly terrors clasp? (34)

The focus shifts from deciphering symbols and suggestive interpretations to that of the several nonhuman/non-living constituents that participate in unveiling a story. Words like 'hammer', 'chain', 'furnace' and 'anvil' are direct representations of tools used by human agencies in reality. It is not just the nonhuman living organisms that construct the definition 
of nature; but also, the nonhuman agencies which are part of human activities come to be defined as being part of nature. Blake's repeated use of tools of labour invites a Marxian perspective, where it is possible to witness how human beings, through their labour, make nature productive. It is not only suggestive of God as a creator, fashioned after human activity (hammer, anvil, etc.), but in order to create, one has to labour no matter who ' $\mathrm{He}$ ' is, and that is the wonder inscribed in the poem.

The poem does not only describe the power of the oriental animal, it also attempts to make the reader aware of a symbolic significance that extends beyond the verbal sequence. Reorienting the interpretation and rereading the poem aims to look at the verbal construct that is generated in a network of words built around a central concept embodied in a main word. The concept of 'tiger', with its many literal and metaphorical meanings, provides the language users a common code or a platform for various other associations to happen. This model, in its arbitrariness, projects a space where different components are spread across and a cumulative meaning is bound to develop in a predetermined system. It is important to note the equivalences (for example, 'symmetry' for 'tiger's stripes') which become the metonymic substitute for the whole system. The emphasis is on reading the kernel word, tiger, in relation to all the lexicons present in the poem, and what Donna Haraway terms as the 'semiotic materiality' (163).

This new narrative is born out of a radical dismantling of the divides between human and nonhuman agencies, between the social and the natural. The dichotomy that ecocriticism cannot avoid is that of nature and culture, while material ecocriticism offers a diffractive thinking and perceives that the social is not different or distinct from the natural. This new dimension of ecocriticism is suggestive of the fact that these narratives emerge through the interaction between entities of nature and culture. It also tells us how cultures are grounded in material facts and come into being by activating upon nature. In order for the theoretical 
discipline of ecocriticism to discard the inherent dichotomy, material ecocriticism envelopes stories that are unveiled through narrative agencies, and that are constructed within the 'material' world. Therefore, the reach of such narratives does not limit itself to history, archaeology and cultural and literary texts, rather it explores the geological, biological and cosmic spaces and divulge the complexities of the world. Material ecocriticism suggests that these narratives emerge through the interaction between entities of nature and culture. The materials become the agents in meaning formation and this in turn becomes consequent upon social and economic processes.

Along with the material, the spaces with which human beings interact and thereby create a dialogic space also become repositories of celebrated stories. It is in this perspective that an understanding of how discursive material looks at the mundane repetitive systems as consequential practices of humans is attempted. It is this material discursive that provides the ecocritical approach a new dimension in examining the causal relationship between the effect on nature when there is a drastic change in culture. The concept reads the entire interaction as a mutual occurrence which brings into examination all those signifying systems and their representations. Material ecocriticism propels an intellectual hybridity where it tries to be inclusive of all the factors that inevitably participate in environmental degradation - cultural, material, psychological, legal and political. Serenella Iovino and Serpil Oppermann offer the following remarks; they define material ecocriticism as;

the study of the way materials forms - bodies, things, elements, toxic substances, chemicals, organic and inorganic matter, landscapes, and biological entities - intra-act with each other and with the human dimension, producing configurations of meanings and discourses that we can interpret as stories. (7) 
By this definition, material ecocriticism does not stand as an independent school of thought, rather it becomes point of contact where various standpoints meet to propose a common theme of perceiving that nonhuman agencies also matter in the entire discourse.

The practitioners of material ecocriticism present their argument of recognising the crucial roles that the nonhuman agencies play in human affairs. Material ecocriticism contests the long-standing idea of the West that brings to the screen the much-propagated divide between culture and nature in terms of civilised and barbaric respectively. It challenges the Western thought as dominated by forms of anthropocentrism which fails to conceive the nonhuman agencies as active participants in the ecological nexus. For instance, the presentday threat received from a virus, Corona, has lesser impact in terms of its direct effect when compared to its impact on other agendas that make up the human society. The investigation of this pandemic outbreak would take us to the history of the Wuhan market in China, which is believed to be the origin of Covid19. The market, from a materialist ecocriticism standpoint, is not merely seen as a trade of wholesale seafood, instead it explores the entry of various nonhuman animals that became part of cuisines over a period of time.

Up until the 1980s, China did not involve itself in wildlife trade, but post 1980s, the trading of domestic creatures, particularly, chicken, goat and pig, fell into the hands of those who could invest capital in breeding of the animals and marketing. The Chinese government encouraged people living in poverty to start their own business which included the raising of wild animals. However, this did not drastically make any change in the overall GDP, because majority people did not consume wildlife or even consider it as part of the regular diet. The minimum purchase that happened was by the expensive hotels that catered to the rich. The sellers had to seek new avenues to market the wildlife animals, and thus, there came about alternatives like selling of different parts of animals as medicinal herbs. This attracted attention and soon, the illegal wildlife trade became rampant, making a greater impact on the 
destruction of wild animals/birds. The fundamental approach was to empower the marginalised people, survival in a market became the material, reflecting the impact on nature when there was a stark visible change in the course of culture.

Furthermore, a referential aspect that emerges often in material ecocriticism is that of 'biosemiotics'. The International Society for Biosemiotics Studies defines biosemiotics as: an interdisciplinary research agenda investigating the myriad forms of communication and signification found in and between living systems. It is thus the study of representation, meaning, sense, and the biological significance of codes and sign processes, from genetic code sequences to intercellular signalling processes to animal display behaviour to human semiotic artefacts such as language and abstract symbolic thought.

The protoscience of biosemiotics enables us to understand the cell-communication which is otherwise known as the quorum sensing. Like human nerve cell, the virus, an infectious agent, is capable of sensing the presence of living organisms in the vicinity through the chemicals present in them. As soon as a virus takes over a host body, it begins by affecting a single body cell, and replicating itself into many through the signals communicated by the inflicted body cell. This coordination of action is what material ecocriticism interprets as a form of narrativity, thus claiming that nonhuman agencies also possess some sort of 'experience'.

Material ecocriticism emphasises on the need to see the ecological as part of political concern. Timothy Morton claims that the presence of semiotic processes in living things, particularly the usage of signs and language, are imposed in the form of sentience on other creatures. The underlying problem is that we fail to recognise the possibility of many forms of sentience and the rapidly increasing cognitive approaches towards nonhuman agencies makes the idea of sentience, especially the human kind, a unitary phenomenon. If the 
emphasis were to be given to the stories of the matter, then those narratives would enable us to fathom meanings of material nexus which is inseparable from the human dimension. In this web of world, every aspect, however important or otherwise, becomes consequential in the social/cultural. As one of the proponents of New Materialism, Karen Barad, puts forth: material ecocriticism as a dimension in ecocriticism that proposes a 'material-discursive' which attempts to bridge the gaps between organic and inorganic, language and nonlanguage, and animate and inanimate.

Our radical approaches, so far, have been in understanding the social as separate from the natural. Barad probes an analysis which enables us to theorise the social and the natural on the same platform. Being aware of the immediate questions, she states very clearly that the consideration of the social and the natural together:

does not mean forcing them together, collapsing important differences between them, or treating them in the same way, but means allowing any integral aspects to emerge. (25)

Donna Haraway defines this as 'natural cultural', a compound term that breaches the schism between nature and culture, while not diluting the significant differences. These conceptual tools help us to theorise humans' dependencies ecosystems and other matter that make up the physical reality.

Though the dimension of material ecocriticism is making a significant impression in the discipline of ecocriticism, Timothy Clark claims that it is also inviting trouble, for in most scenarios, it is rendered quasi-philosophical superstructure on the nature of its claims.As mentioned earlier, we see postmodern ecocriticism being contested in a manner, such attempts may risk: 
badly over-intellectualising the issues behind human over-exploitation of the natural world, and caricaturing as an academic problem what is more truly and intractably a political, social, psychological and ecological one. (132)

It is, therefore, imperative to remain cautious of this fact and proceed to perceive material ecocriticism as an ecocritical development of the traditional method of reading a text which not only includes its historical context but also the precise political and economic circumstances of the time. Material ecocriticism implores us to read the world as a text, which would then ask us to arrive at accurate interpretations of this newly found text. Such interpretations become necessary and important for social reforms to come about in terms of cognitive justice, political liberation and environmental responsiveness. 


\section{Works Cited}

"What is Biosemiotics?". International Society for Biosemiotic Studies (ISBS), date of access:

9 Nov. 2020. www.biosemiotic.org.

Barad, Karen. Meeting the Universe Halfway: Quantum Physics and the Entanglement of Matter and Meaning. 2nd ed., Duke University Press,2007.

Blake, William. Songs of Innocence and of Experience. DjVu Editions E-books, 2001.

Bowra, Maurice. The Romantic Imagination. Oxford University Press, 2018.

Clark, Timothy. The Value of Ecocriticism. Cambridge University Press, 2019.

Coole, Diana and Samantha Frost. "Introducing the New Materialisms". New Materialisms: Ontology, Agency, and Politics edited by Diana Coole and Samantha Frost. Duke University Press, 2010.

Haraway, Donna. When Species Meet. University of Minnesota Press, 2008.

Iovino, Serenella and Serpil Oppermann. 2014. "Introduction: Stories Come to Matter". Material Ecocriticism edited by Serenella Iovino and Serpil Oppermann.Indiana University Press, 2014.

Morton, Timothy. Ecology without Nature: Rethinking Environmental Aesthetics. Harvard University Press, 2007.

Oppermann, Serpil. "Material Ecocriticism and the Creativity of Storied Matter". Frame. vol.26, no.2, Nov.2013, pp. 55-69.

_ "Theorizing Ecocriticism: Toward a Postmodern Ecocritical Practice". Interdisciplinary Studies in Literature and Environment. vol.13, no.2, Summer 2006, pp.103-128. Riffaterre, Michael. “Interpretation and Descriptive Poetry: A Reading of Wordsworth's “Yew-Trees"”. New Literary History. vol.4, no.2, 1973, pp. 229-256. 